FINANCIAL: Jurnal Akuntansi

Published by Program Studi Akuntansi STIE Sultan Agung Volume 5-Nomor 2, Desember 2019, (HIm 22-29)

ISSN-P: 2502-4574, ISSN-E: 2686-2581

Available online at: https://financial.ac.id/index.php/financial

\title{
LAPORAN ARUS KAS UNTUK MENILAI KINERJA KEUANGAN PADA PT KALBE FARMA, TbK YANG TERDAFTAR DI BURSA EFEK INDONESIA
}

\author{
Misseri Yolanda Sitohang ${ }^{1 *}$, Yansen Siahaan ${ }^{2)}$, Astuti $^{3)}$, Musa F. Silaen ${ }^{4)}$ \\ ${ }^{1}$ Program Studi Akuntansi, STIE Sultan Agung, Pematangsiantar, Sumatera Utara, Indonesia \\ ${ }^{2}$ Program Studi Akuntansi, STIE Sultan Agung, Pematangsiantar, Sumatera Utara, Indonesia \\ ${ }^{3}$ Program Studi Akuntansi, STIE Sultan Agung, Pematangsiantar, Sumatera Utara, Indonesia \\ ${ }^{4}$ Program Studi Akuntansi, STIE Sultan Agung, Pematangsiantar, Sumatera Utara, Indonesia \\ *Email: ${ }^{1}$ misserisitohang@gmail.com, ${ }^{2}$ yansensiahaan@ @stiesultanagung.ac.id, \\ ${ }^{3}$ astuti@stiesultanagung.ac.id, ${ }^{4}$ musasilaen@stiesultanagung.ac.id
}

\begin{abstract}
Abstrak
Tujuan dari penelitian ini adalah untuk mengetahui gambaran laporan arus kas dan kinerja keuangan dan untuk mengetahui faktor-faktor yang menyebabkan kinerja keuangan PT Kalbe Farma, Tbk yang terdaftar di Bursa Efek Indonesia yang menggunakan analisis rasio arus kas cenderung mengalami peningkatan. Penelitian ini dilakukan dengan menggunakan metode analisis deskriptif kualitatif dan analisis induktif. Jenis data yang digunakan dalam penelitian ini adalah data kualitatif dan kuantitatif. Sumber data yang digunakan adalah data sekunder. Hasil penelitian ini disimpulkan bahwa kinerja keuangan yang diukur menggunakan rasio arus kas operasi terhadap kewajiban lancar, rasio arus kas operasi terhadap pengeluaran modal, rasio arus kas operasi terhadap total utang dan rasio arus kas operasi terhadap laba bersih cenderung meningkat. Faktor peningkatan penerimaan kas dari pelanggan, penurunan utang bank jangka pendek dan liabilitas pajak tangguhan serta peningkatan pembelian aset tetap dan penjualan neto yang menyebabkan peningkatan kinerja keuangan.
\end{abstract}

Kata kunci: Laporan Arus Kas, Kinerja Keuangan

\section{CASH FLOW STATEMENT TO ASSESS THE FINANCIAL PERFORMANCE OF PT KALBE FARMA, TbK LISTED IN INDONESIA STOCK EXCHANGE}

\begin{abstract}
The purpose of this research are to determine the description of cash statements and financial performance, to determine the factors that lead the increase of financial performance at PT Kalbe Farma, Tbk listed on the Indonesia Stock Exchange that use analysis cash flow ratio. The research was done by using descriptive analysis method and analysis inductive. The types of data used in this research are qualitative data and quantitative data. Source of data used secondary data. The result of this research can be concluded as the financial performance that measured by the ratio of operating cash flows to current liabilities, the ratio of operating cash flows to capital expenditure, the ratio of operating cash flows to total debt, and the ratio of operating cash flows to net income tend increase. Factors of the increase of cash received from customers, the decrease of short-term bank loans and deferred tax liabilities and the increase of acquisitions of property, plant and equipment and net sales that cause of the increase of financial performance.
\end{abstract}

Keywords: Cash Flow Statement, Financial Performance

Article History: Received: 18 Sep 2019 Revised: 20 Sep 2019 Accepted: 29 Okt 2019 


\section{PENDAHULUAN}

Kinerja keuangan menggambarkan pencapaian perusahaan dalam menghasilkan laba. Setiap perusahaan memiliki standar kinerja yang ditetapkan sebelumnya dan dikatakan berhasil jika mencapai standar tersebut. Untuk itu, diperlukan pengukuran kinerja keuangan yang biasanya dilakukan bersamaan dengan analisis kinerja keuangan. Seluruh informasi mengenai kinerja keuangan perusahaan selama periode tertentu dapat diperoleh melalui laporan keuangan. Salah satu bagian laporan keuangan yang dapat digunakan untuk mengukur kinerja keuangan adalah laporan arus kas.

Analisis laporan arus kas digunakan untuk mengetahui kas yang tersedia untuk memenuhi kebutuhan kas jangka pendeknya, jumlah kas dari aktivitas operasi, serta menganalisis apakah rencana perusahaan dalam investasi dan pendanaan berjalan sesuai yang diinginkan. Alat ukur yang digunakan untuk menganalisis laporan arus kas adalah rasio arus kas. Rasio arus kas yang digunakan untuk menilai kinerja keuangan suatu perusahaan terdiri dari Rasio Arus Kas Operasi Terhadap Kewajiban Lancar, Rasio Arus Kas Operasi Terhadap Bunga, Rasio Arus Kas Operasi Terhadap Pengeluaran Modal, Rasio Arus Kas Operasi Terhadap Total Utang, dan Rasio Arus Kas Operasi Terhadap Laba Bersih.

PT Kalbe Farma, Tbk merupakan perusahaan farmasi terbuka sebagai penyedia solusi kesehatan mulai dari obat resep dan obat bebas, produk-produk minuman energi dan nutrisi, hingga peralatan medis, termasuk layanan kesehatan yang beralamat di Jakarta. Perusahaan ini memiliki empat kelompok divisi usaha yaitu divisi obat resep, divisi produk kesehatan, divisi nutrisi, serta divisi distribusi dan logistik.

Kinerja keuangan yang diukur menggunakan rasio arus kas operasi terhadap kewajiban lancar, rasio arus kas operasi terhadap pengeluaran modal, rasio arus kas operasi terhadap total utang dan rasio arus kas operasi terhadap laba bersih pada PT Kalbe Farma, Tbk mengalami fluktuasi namun cenderung meningkat. Namun rasio arus kas operasi terhadap kewajiban lancar memiliki rata-rata di bawah 1 yaitu sebesar 0,84 sehingga perusahaan tidak mampu membayar kewajiban lancarnya melalui kas dari aktivitas operasi. Hal ini sesuai dengan pendapat Hery (2014), "rasio arus kas operasi terhadap kewajiban lancar di bawah 1 berarti perusahaan tersebut tidak mampu melunasi kewajiban lancarnya hanya dengan menggunakan arus kas operasi saja".

Hasil perhitungan untuk rasio arus kas terhadap laba bersih menunjukkan rata-rata berada di bawah 1 yaitu sebesar 0,90 yang menunjukkan jumlah arus kas dari aktivitas operasi masih lebih rendah dibandingkan jumlah laba bersih yang di dalamnya terdapat beban non kas yang sifatnya mengurangi laba bersih yang berarti kinerja keuangan kurang baik. Hal ini tidak sejalan dengan pendapat Hery (2014) yang menyatakan, "pada umumnya rasio arus kas operasi terhadap laba bersih memiliki nilai di atas 1 karena adanya non cash expenses (beban-beban yang tidak memerlukan pengeluaran kas)".

Rumusan masalah dalam penelitian ini adalah bagaimana gambaran laporan arus kas dan kinerja keuangan serta faktor apa yang menyebabkan kinerja keuangan PT Kalbe Farma, Tbk yang terdaftar di Bursa Efek Indonesia yang menggunakan 
analisis rasio arus kas cenderung mengalami peningkatan. Tujuan penelitian adalah untuk mengetahui gambaran laporan arus kas dan kinerja keuangan serta mengetahui faktor yang menyebabkan kinerja keuangan PT Kalbe Farma, Tbk yang terdaftar di Bursa Efek Indonesia yang menggunakan analisis rasio arus kas cenderung mengalami peningkatan.

\section{LANDASAN TEORI}

Akuntansi adalah sistem informasi yang menghasilkan informasi keuangan kepada pihak-pihak yang berkepentingan mengenai aktivitas ekonomi dan kondisi suatu perusahaan (Rudianto, 2012). Tujuan utama akuntansi adalah menyajikan informasi ekonomi (economic information) dari suatu kesatuan ekonomi (economic entity) kepada pihak-pihak yang berkepentingan (Soemarso, 2004).

Analisis laporan keuangan terdiri dari dua bagian kata, yaitu "analisis" dan laporan keuangan". Analisis adalah penguraian suatu persoalan atau permasalahan serta menjelaskan mengenai hubungan antara bagianbagian yang ada di dalamnya untuk selanjutnya diperoleh suatu pengertian secara keseluruhan. Sedangkan laporan keuangan adalah suatu penyajian terstruktur dari posisi keuangan dan kinerja keuangan suatu entitas. Tujuan analisis laporan keuangan mempunyai maksud untuk menegaskan apa yang diinginkan atau diperoleh dari analisis yang dilakukan. Dengan adanya tujuan, analisis selanjutnya akan dapat terarah, memiliki batasan dan hasil yang ingin dicapai (Maith, 2013).

Laporan arus kas disusun dengan tujuan untuk memberikan informasi historis mengenai perubahan kas dari suatu Copyright (C) 2019, FINANCIAL: Jurnal Akuntansi perusahaan, dengan mengklasifikasikan arus kas berdasarkan aktivitas operasi, investasi, dan pendanaan selama periode tertentu. Dengan demikian, tujuan utama laporan arus kas adalah untuk memberikan kepada para pengguna informasi tentang mengapa posisi kas perusahaan berubah selama periode tertentu (Afriyeni, 2013).

Analisis laporan arus kas berguna dalam mengevaluasi posisi dan operasi perusahaan dan dilakukan perbandingan dengan tahun-tahun sebelumnya sehingga dapat diketahui baik tidaknya kinerja perusahaan dalam beroperasi. Setiap perusahaan dalam menjalankan operasi usahanya akan mengalami arus masuk (cash in flow) dan arus kas keluar (cash out flows) (Warongan, Ventje dan Natalia, 2018).

Menurut Hery (2014), "data laporan arus kas dapat digunakan untuk menghitung rasio tertentu yang menggambarkan kekuatan keuangan perusahaan. Analisis laporan arus kas ini menggunakan komponen laporan arus kas dan juga komponen neraca serta laporan laba-rugi sebagai alat analisis rasio". Rasio arus kas yang dimaksud terdiri atas:

1. Rasio Arus Kas Operasi Terhadap Kewajiban Lancar

Rasio ini menunjukkan kemampuan arus kas operasi perusahaan dalam melunasi kewajiban lancarnya. Rasio ini dihitung sebagai hasil bagi antara arus kas operasi dengan total kewajiban lancar.

Rasio Arus Kas Operasi terhadap Kewajiban Lancar $=\frac{\text { Arus Kas Operasi }}{\text { Kewajiban Lancar }}$

2. Rasio Arus Kas Operasi Terhadap Bunga 
Karena pembayaran bunga harus dilakukan dengan menggunakan kas, maka diperlukan suatu rasio yang menunjukkan kemampuan perusahaan dalam membayar bunga pinjaman kepada kreditor, yang mana dananya bersumber dari arus kas operasi perusahaan. Rasio yang dimaksud adalah rasio arus kas operasi terhadap bunga.

Rasio Arus Kas Operasi terhadap Bunga

$=\frac{\text { Arus Kas Operasi }+ \text { Bunga }+ \text { Pajak }}{\text { Bunga }}$

3. Rasio Arus Kas Operasi Terhadap Pengeluaran Modal

Rasio ini digunakan untuk mengukur arus kas operasi yang tersedia untuk pengeluaran investasi. Rasio ini dihitung sebagai hasil bagi antara arus kas operasi dengan kas yang dibayarkan untuk pengeluaran modal, seperti pembelian aset tetap, akuisisi bisnis, dan aktivitas investasi lainnya.

Rasio Arus Kas Operasi terhadap Pengeluara n Modal

$$
=\frac{\text { Arus Kas Operasi }}{\text { Pengeluara n Modal }}
$$

4. Rasio Arus Kas Operasi Terhadap Total Utang

Rasio arus kas operasi terhadap total utang menunjukkan kemampuan arus kas operasi perusahaan dalam melunasi seluruh kewajibannya, baik kewajiban lancar maupun kewajiban jangka panjang. Rasio ini dihitung sebagai hasil bagi antara arus kas operasi dengan total utang.

$$
\begin{aligned}
\text { Rasio Arus } & \text { Kas Operasi terhadap Total Utang } \\
= & \frac{\text { Arus Kas Operasi }}{\text { Total Utang }}
\end{aligned}
$$

5. Rasio Arus Kas Operasi Terhadap Laba Bersih

Rasio arus kas operasi terhadap laba bersih menunjukkan seberapa jauh penyesuaian dan asumsi akuntansi

Copyright (C) 2019, FINANCIAL: Jurnal Akuntansi akrual mempengaruhi perhitungan laba bersih. Rasio ini dihitung sebagai hasil bagi antara arus kas operasi dengan laba bersih.

$$
\begin{aligned}
\text { Rasio Arus } & \text { Kas Operasi terhadap Laba Bersih } \\
= & \frac{\text { Arus Kas Operasi }}{\text { Laba Bersih }}
\end{aligned}
$$

Analisis kinerja keuangan merupakan suatu proses pengkajian kinerja keuangan secara kritis, yang meliputi peninjauan data keuangan, penghitungan, pengukuran, interpretasi, dan pemberian solusi terhadap masalah keuangan perusahaan pada suatu periode tertentu (Warongan, Ventje dan Natalia, 2018). Dalam penelitian ini, alat analisis yang digunakan untuk menilai kondisi dan kinerja keuangan perusahaan adalah hasil rasio keuangan yang menghubungkan dua data keuangan dengan jalan membagi suatu data dengan data lainnya. Rasio keuangan ini diperoleh atau dihitung dari laporan keuangan yang dihasilkan merupakan ikhtisar mengenai keuangan suatu perusahaan. Sehingga, rasio yang akan digunakan untuk menilai kinerja keuangan berdasarkan laporan arus kas adalah rasio arus kas.

Kinerja keuangan perusahaan dikatakan baik atau tidak baik apabila (Hery, 2014):

1. Rasio arus kas operasi terhadap kewajiban lancar di bawah 1 berarti bahwa perusahaan tersebut tidak mampu melunasi kewajiban lancarnya hanya dengan menggunakan arus kas operasi saja.

2. Rasio arus kas operasi terhadap pengeluaran modal, rasio yang tinggi menunjukkan kemampuan yang tinggi pula dari arus kas operasi perusahaan dalam membiayai pengeluaran modal (pembelian tambahan aset tetap, 
melakukan investasi, ataupun akuisisi). Rasio yang rendah menunjukkan bahwa perusahaan harus mencari pendanaan eksternal (seperti melalui pinjaman dari kreditor ataupun tambahan dana dari investor) untuk membiayai ekspansi atau perluasan usahanya.

3. Rasio arus kas operasi terhadap total utang, rasio yang rendah menunjukkan bahwa perusahaan memiliki kemampuan yang kurang baik dalam membayar semua kewajibannya dengan menggunakan arus kas yang berasal dari aktivitas normal operasi perusahaan.

4. Rasio arus kas operasi terhadap laba bersih, pada umumnya rasio ini memiliki nilai di atas 1 karena adanya non cash expenses (beban-beban yang tidak memerlukan pengeluaran kas), seperti beban penyusutan, beban amortisasi, dan beban piutang tak tertagih yang sifatnya mengurangi laba bersih namun tidak berdampak terhadap arus kas operasi. Semakin tinggi rasio ini menunjukkan bahwa kinerja keuangan perusahaan semakin baik, meskipun dengan jumlah laba bersih yang kecil sebagai akibat besarnya beban non kas.

\section{METODE}

Dalam penelitian ini, objek penelitian yang penulis gunakan adalah laporan keuangan PT Kalbe Farma, Tbk selama 5 tahun terakhir yaitu dari tahun 2013 sampai dengan 2017 yang telah diaudit. Desain penelitian yang digunakan adalah penelitian kepustakaan (library research) yang menggunakan data sekunder dengan cara mengakses dari situs http://www.idx.co.id. Ruang lingkup Copyright (C) 2019, FINANCIAL: Jurnal Akuntansi penelitian adalah laporan keuangan PT Kalbe Farma, Tbk periode 2013-2017. Variabel yang diteliti adalah laporan arus kas (X) dan kinerja keuangan (Y) pada PT Kalbe Farma, Tbk dari tahun 2013 sampai dengan 2017 dengan menggunakan alat ukur rasio arus kas yang terdiri dari rasio arus kas operasi terhadap kewajiban lancar, rasio arus kas operasi terhadap pengeluaran modal, rasio arus kas operasi terhadap total utang, dan rasio arus kas operasi terhadap laba bersih. Dalam penelitian ini, penulis menggunakan data kualitatif dan data kuantitatif. Teknik pengumpulan data adalah teknik dokumentasi dengan cara mencari data dari buku, jurnal akuntansi, surat kabar, dan dokumen-dokumen yang terkait dengan penelitian ini serta media internet dengan cara mengunduh laporan keuangan melalui situs resmi Bursa Efek Indonesia dan PT Kalbe Farma, Tbk. Teknik analisis data yang digunakan adalah analisis deskriptif kualitatif dan analisis induktif.

\section{HASIL DAN PEMBAHASAN}

Dalam penelitian ini, penulis menggunakan rasio arus kas operasi terhadap kewajiban lancar, rasio arus kas operasi terhadap pengeluaran modal, rasio arus kas operasi terhadap total utang dan rasio arus kas operasi terhadap laba bersih untuk mengukur kinerja keuangan PT Kalbe Farma, Tbk yang disajikan dalam Tabel 1 berikut ini:

Tabel 1. Gambaran Kinerja Keuangan Menggunakan Rasio Arus Kas PT Kalbe Farma, Tbk yang Terdaftar di Bursa Efek Indonesia Periode 2013-2017 


\begin{tabular}{|c|c|c|c|c|}
\hline Tahun & $\begin{array}{c}\text { Rasio Arus } \\
\text { Kas } \\
\text { Operasi } \\
\text { terhadap } \\
\text { Kewajiban } \\
\text { Lancar }\end{array}$ & $\begin{array}{c}\text { Rasio Arus } \\
\text { Kas Operasi } \\
\text { terhadap } \\
\text { Pengeluaran } \\
\text { Modal }\end{array}$ & $\begin{array}{c}\text { Rasio } \\
\text { Arus Kas } \\
\text { Operasi } \\
\text { terhadap } \\
\text { Total } \\
\text { Utang }\end{array}$ & $\begin{array}{c}\text { Rasio } \\
\text { Arus Kas } \\
\text { Operasi } \\
\text { terhadap } \\
\text { Laba } \\
\text { Bersih }\end{array}$ \\
\hline 2013 & 0,35 & 0,93 & 0,329 & 0,47 \\
\hline 2014 & 0,97 & 3,09 & 0,888 & 1,09 \\
\hline 2015 & 1,04 & 2,72 & 0,891 & 1,19 \\
\hline 2016 & 0,93 & 2,08 & 0,782 & 0,92 \\
\hline 2017 & 0,90 & 1,73 & 0,738 & 0,82 \\
\hline
\end{tabular}

Sumber: Data diolah dari laporan keuangan PT Kalbe Farma, Tbk, 2019

Dari tahun 2013-2017, keempat rasio arus kas yakni rasio arus kas operasi terhadap kewajiban lancar, rasio arus kas operasi terhadap pengeluaran modal, rasio arus kas operasi terhadap total utang dan rasio arus kas operasi terhadap laba bersih mengalami peningkatan. Dari tabel 3.5 dapat diambil kesimpulan bahwa dari tahun 2013 sampai dengan tahun 2017, kinerja keuangan mengalami peningkatan. Rasio arus kas operasi terhadap kewajiban lancar tahun 2013 sampai dengan tahun 2017, mengalami peningkatan dikarenakan peningkatan penerimaan kas dari pelanggan dan penurunan utang bank jangka pendek namun menunjukkan pencapaian di bawah 1 sehingga perusahaan tidak mampu melunasi kewajiban lancarnya hanya dengan menggunakan arus kas dari aktivitas normal perusahaan. Sedangkan rasio arus kas operasi terhadap pengeluaran modal selama 5 tahun berturut-turut terlihat mengalami peningkatan dari tahun 20132017 yang disebabkan persentase peningkatan arus kas dari aktivitas operasi lebih besar dibandingkan persentase peningkatan pengeluaran modal yaitu pembelian aset tetap.

Selain itu, rasio arus kas operasi terhadap total utang mengalami peningkatan disebabkan peningkatan penerimaan kas dari pelanggan dan penurunan utang bank jangka pendek dan liabilitas pajak tangguhan. Hal ini menunjukkan perusahaan memilki kemampuan yang semakin baik dalam membayar total utang perusahaan menggunakan arus kas dari aktivitas operasi perusahaan namun tidak bisa tertutupi sepenuhnya menggunakan kas tersebut dan masih membutuhkan pendanaan eksternal. Rasio arus kas operasi terhadap laba bersih cenderung mengalami peningkatan disebabkan persentase peningkatan arus kas dari aktivitas operasi lebih besar dibandingkan persentase peningkatan laba bersih dari tahun 2013-2017 yang berarti kinerja keuangan perusahaan membaik. Namun, nilai rasio ini memiliki rata-rata di bawah 1 yang berarti jumlah arus kas dari aktivitas operasi masih lebih rendah dibandingkan jumlah laba bersih yang di dalamnya terdapat beban non kas seperti beban penyusutan aset tetap dan beban penghapusan persediaan (sumber: notes 14, 30 dan 35) yang sifatnya mengurangi laba bersih.

Dari periode 2013-2017, rasio arus kas operasi terhadap kewajiban lancar PT Kalbe Farma, Tbk yang terdaftar di Bursa Efek Indonesia berfluktuasi dan cenderung mengalami peningkatan, hal ini disebabkan peningkatan arus kas dari aktivitas operasi yang didominasi peningkatan penerimaan kas dari pelanggan dan penurunan jumlah kewajiban lancar terutama utang bank jangka pendek. Namun nilai rata-rata rasio arus kas operasi terhadap kewajiban lancar masih berada di bawah 1 sehingga sesuai dengan teori menurut Hery (2014:106) dapat dikatakan kinerja keuangan tidak baik yang berarti perusahaan tidak mampu melunasi utang yang akan jatuh tempo 
melalui kas yang dihasilkan dari aktivitas operasi.

Rasio arus kas operasi terhadap pengeluaran modal PT Kalbe Farma, Tbk yang terdaftar di Bursa Efek Indonesia periode 2013-2017 berfluktuasi dan cenderung mengalami peningkatan. Hal ini dikarenakan jumlah arus kas dari aktivitas operasi yang didominasi penerimaan kas dari pelanggan dan pengeluaran modal berupa pembelian aset tetap mengalami peningkatan namun persentase peningkatan arus kas dari aktivitas operasi lebih besar dibandingkan pengeluaran modal. Sesuai dengan teori dapat dikatakan rasio arus kas operasi terhadap pengeluaran modal menunjukkan kinerja keuangan yang semakin baik.

PT Kalbe Farma, Tbk yang terdaftar di Bursa Efek Indonesia periode 20132017 menunjukkan rasio arus kas operasi terhadap total utang yang berfluktuasi dan cenderung mengalami peningkatan. Hal ini disebabkan peningkatan jumlah arus kas dari aktivitas operasi dimana salah satunya adalah peningkatan penerimaan kas dari pelanggan dan penurunan total utang terutama utang bank jangka pendek dan liabilitas pajak tangguhan. Sesuai dengan teori dapat dikatakan rasio arus kas operasi terhadap total utang menunjukkan kinerja keuangan yang semakin baik. Namun kas dari aktivitas operasi tidak dapat sepenuhnya menutupi total utang yang didominasi liabilitas jangka pendek.

Rasio arus kas operasi terhadap laba bersih PT Kalbe Farma, Tbk yang terdaftar di Bursa Efek Indonesia periode 200132017 berfluktuasi dan cenderung mengalami peningkatan yang disebabkan persentase peningkatan arus kas dari aktivitas operasi sebesar 116,61 \% lebih besar dibandingkan peningkatan laba Copyright (C) 2019, FINANCIAL: Jurnal Akuntansi bersih sebesar 24,50\%. Peningkatan laba bersih bersumber dari peningkatan penjualan neto dan peningkatan arus kas dari aktivitas operasi didominasi penerimaan kas dari pelanggan. Namun rasio ini masih memiliki nilai rata-rata di bawah 1. Hal ini tidak sesuai dengan teori menurut Hery (2014) yang menyatakan pada umumnya rasio arus kas operasi terhadap laba bersih memiliki nilai di atas 1 yang berarti kinerja keuangan kurang baik.

Berdasarkan analisis rasio arus kas untuk menilai kinerja keuangan PT Kalbe Farma, Tbk yang terdaftar di Bursa Efek Indonesia dapat diketahui bahwa rasio arus kas menunjukkan kinerja keuangan yang semakin baik karena dari empat rasio yang diperhitungkan dalam menilai kinerja keuangan seluruhnya menunjukkan trend yang cenderung mengalami peningkatan. Namun untuk rasio arus kas operasi terhadap kewajiban lancar dan rasio arus kas operasi terhadap laba bersih masih memiliki nilai di bawah standar yaitu berada di bawah 1. Tetapi secara keseluruhan kinerja keuangan PT Kalbe Farma, Tbk yang terdaftar di Bursa Efek Indonesia selama 5 tahun yang dinilai dengan analisis rasio arus kas cenderung mengalami peningkatan.

\section{SIMPULAN DAN SARAN}

Simpulan dari penelitian ini adalah rasio arus kas operasi terhadap kewajiban lancar, rasio arus kas operasi terhadap pengeluaran modal, rasio arus kas operasi terhadap total utang dan rasio arus kas operasi terhadap laba bersih PT Kalbe Farma, Tbk yang terdaftar di Bursa Efek Indonesia cenderung mengalami peningkatan disebabkan peningkatan arus kas dari aktivitas operasi yang didominasi 
peningkatan penerimaan kas dari pelanggan, penurunan kewajiban lancar pada utang bank jangka pendek, peningkatan pengeluaran modal berupa pembelian aset tetap, penurunan total utang terutama utang bank jangka pendek dan liabilitas pajak tangguhan, serta peningkatan laba bersih terutama peningkatan penjualan neto.

Saran yang dapat diberikan penulis adalah sebaiknya PT Kalbe Farma, Tbk lebih memperhatikan manajemen utang sehingga dapat memperkirakan kas yang akan digunakan untuk melunasi liabilitas jangka pendek, memanfaatkan utang bank jangka pendek secara optimal untuk mengelola kegiatan operasi sehingga meningkatkan penjualan dan laba yang berarti menambah penerimaan kas dari pelanggan, meningkatkan penjualan dan laba serta kemampuan penagihan piutang yang telah jatuh tempo agar dapat digunakan untuk kegiatan operasional perusahaan sehingga kas yang dihasilkan dari aktivitas operasi tidak jauh berbeda dengan laba yang diperoleh. Untuk peneliti selanjutnya dapat menambah tahun penelitian atau menambah objek penelitian agar hasil penelitian dapat digeneralisir.

\section{DAFTAR PUSTAKA}

Afriyeni. (2013). Analisis Laporan Arus Kas untuk Mengukur Kinerja Keuangan Pada PT. Indofood Sukses Makmur, Tbk. Buletin Ilmiah Keuangan dan Perbankan volume 6 no. 1, mei 2013.

Hery. (2014). Analisis Kinerja Manajemen. Jakarta: PT Grasindo.

, Hendry Andres (2013). Analisis Laporan Keuangan dalam Mengukur Kinerja Keuangan Pada PT. Hanjaya Mandala Sampoerna Tbk. Jurnal EMBA vol.1 no.3 September 2013, hal. 619-628.
Rudianto. (2012). Pengantar Akuntansi, Konsep dan Teknik Penyusunan Laporan Keuangan, Adaptasi IFRS. Jakarta: Erlangga.

Soemarso, S. R. (2004). Akuntansi Suatu Pengantar. Buku 1, Edisi Kelima. Jakarta: Salembmata Empat.

Warongan, Megi Sila Jona, Ventje Ilat, dan Natalia Gerungai. (2018). Analisis Rasio Arus Kas dalam Menilai Kinerja Keuangan Pada PT. PLN (Persero) Wilayah Suluttenggo. Jurnal Riset Akuntansi Going Concern 13(2), 2018, 453-463.

\section{PROFIL SINGKAT}

Misseri Yolanda Sitohang, lahir di Kabupaten Simalungun, pada tanggal 23 Juli tahun 1997. Baru saja menyelesaikan pendidikan Sarjana Ekonomi pada Program Studi Akuntansi di STIE Sultan Agung pada tahun 2019. Yansen Siahaan, lahir di Pematangsiantar pada tanggal 15 Nopember tahun 1955. Menyelesaikan pendidikan Doktor pada Program Studi Ilmu Akuntansi di Universitas Sumatera Utara pada tahun 2018. Saat ini beliau menjabat sebagai Ketua Program Studi Sarjana Akuntansi di STIE Sultan Agung. Astuti, lahir di Pematangsiantar pada tanggal 28 Pebruari 1991. Menyelesaikan pendidikan Magister pada Program Studi Akuntansi di Universitas Sumatera Utara pada tahun 2017. Saat ini beliau beraktivitas sebagai Dosen Tetap di STIE Sultan Agung. Musa F. Silaen lahir di pematangsiantar pada tanggal 15 April 1987. Menyelesaikan pendidikan Magister pada Program Studi Akuntansi di Universitas Muhammadiyah Sumatera Utara pada tahun 2018. Saat ini beliau beraktivitas sebagai Dosen Tetap di STIE Sultan Agung. 